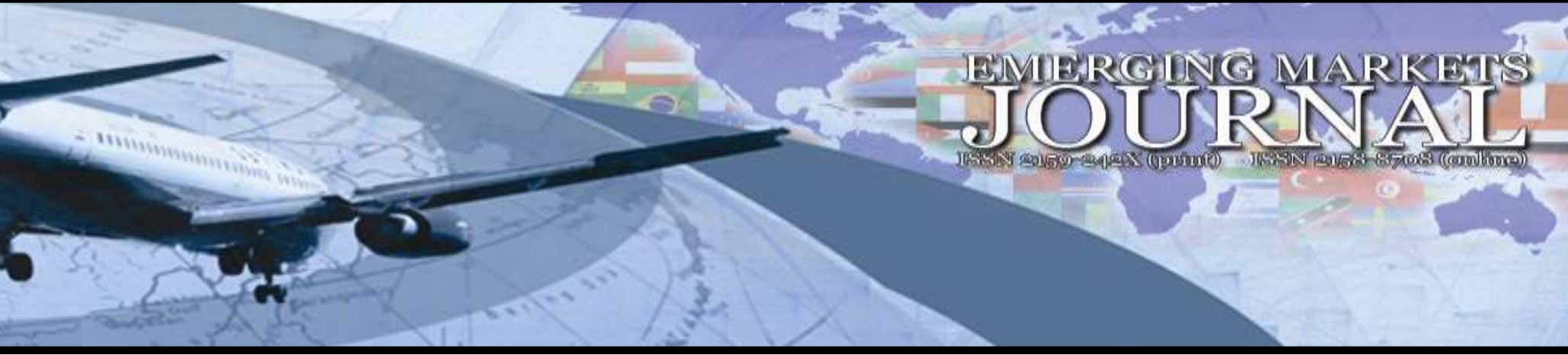

\title{
The Influence of Oil Price Uncertainty on Economic Activities in Nigeria
}

\section{Samson Ogege}

University of Lagos, Nigeria | ogegesamson@yahoo.com

\section{Tarila Boloupremo}

University of Africa, Toru-Orua, Nigeria | taribolou@yahoo.com

Volume 10 No 2 (2020) ｜ＩSSN 2158-8708 (online) ｜ DOI 10.5195/emaj.2020.195 | http://emaj.pitt.edu

\begin{abstract}
This paper seeks to appraise the uncertainty of oil price influence on the activities of Nigerian economy with regard to human development in Nigeria. The research utilized the annual time series data spanning between 1981-2018, and the stationarity of the observed variables was tested by carrying out a unit root test and the stationarity of most of the observed variables were revealed at first difference. The secondary data employed were analyzed with the aid of least square technique of data analysis to assess the association between the observed variables. In response to the outcomes of the analysis, it was revealed that crude oil price positively and insignificantly influences life expectancy, but significantly influences consumption per capital and contrarily, it revealed negative and insignificant influence on physical quality of life and education index. It was inferred by the study that, there is existence of a comparative association of oil price with the indicators of Nigerian economic development. However, there is divergence of influence of the mechanisms of economic attributes as well as performance indicators. The study recommends that, a strict measure of monetary policy should be adopted by the government to regulate the rates of interest and inflation in the economy on a regular basis.
\end{abstract}

Keywords: Crude Oil Price, Economic Development, Human Development, Life Expectancy, Performance Indicators

\section{$(\mathrm{Cc}) \mathrm{EY}$}

New articles in this journal are licensed under a Creative Commons Attribution 3.0 United States License.

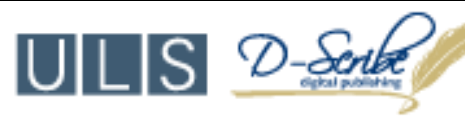

This journal is published by the University Library System of the University of Pittsburgh as part

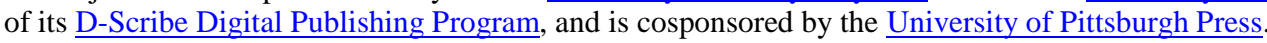




\section{The Influence of Oil Price Uncertainty on Economic Activities in Nigeria}

\author{
Samson Ogege \\ Tarila Boloupremo
}

\section{Introduction}

For decades, it has become a tradition for the Nigerian economy to be exclusively dependent on crude oil and it has as well become a yardstick for determining the national budget and planning, revenue sharing and the allocation of capital. Oil price shock is viewed as the unstable movement of global prices of oil. It is quite significant to assert that, the determinant factors of oil price are exogenous in nature and are beyond the control of Nigeria. Thus, it causes stagnation in the Naira value and that Nigeria as a country does not have the potential to independently control the causes of the upward and downward movement in the oil price. Due to the significant role crude oil plays in revamping and resuscitating the country's economy as well as its political fate, it has become the main source of generating revenue for the Nigerian economy. The fluctuations in the oil price have had a resultant multiplier effect on the activities of country's economy. Crude oil's influence on the economic activities of Nigeria has been ascertained to be positive and negative. Its influence is positive in the sense that it presents a lot of benefits to the country in diverse means, and has negatively ended up to be a curse (Ogwumike and Ogunleye, 2008).

In comparison with other African nations' economy, the economy of Nigerian has maintained a substantial track record of growth via extensive free trade as well as privatization. The consumption of petroleum as well as total energy within the West African subregion are continually influenced and dominated by the Nigerian economy. Notwithstanding, being a net exporter of crude oil, Nigeria keeps on relying exclusively on the returns from crude oil and as a matter of fact, it is anticipated to be affected or influenced by the shock in the global price of oil. Based on the stand point of the consumer, any increase in the price of oil would in return breed inflation on the ground that, the prices of commodities manufactured by petroleum products increase. Furthermore, there will be a general increase in the cost of production as well as transportation among others. In view of the perspective of the producer, most firms are faced with increased cost production/operation which has affected their profitability level adversely and has resulted in a decrease in firms' productivity, which by implication has posed adverse effects on investment and employment as well as breed inflation.

Several empirical studies have adopted volatility to measure uncertainty in the price of oil. Elder and Serletis (2010) and recently in the studies of
Baumeister and Kilian (2016) as well as Demirbas et al. (2017), oil prices volatility was evidently documented. Furthermore, it has been revealed in the research of Junior and Goodness (2018) as well as Alley et al. (2014) that, the uncertainty in the price of oil significantly influences economic activity and it is anticipated that these significances fluctuate between oil exporting and importing nations. The problem of this study takes into cognizance the essence of understanding the oil price's influence on four basic economic components (life expectancy, education, physical quality of life, and consumption per capita) in Nigeria. Therefore, the researcher attempts to appraise the existence of association between oil price and index of economic development. The focal point of this study is to appraise the uncertainty of oil price influence on the activities of Nigerian economy with regard to human development in Nigeria. However, the specific objectives are to ascertain how oil price uncertainty influences life expectancy in Nigeria, investigate the effect of the uncertainty of oil price on education index in Nigeria, appraise the oil price uncertainty's influence on consumption per capital in Nigeria and assess how oil price uncertainty impacts on physical quality of life index in Nigeria.

\section{Literature Review}

Based on the structural theory, the volatility of the macroeconomic variables could be accountable for the structural shocks in the economy for instance, when there is sudden huge amount of variations in the prices of oil and food (Sommer, 2002). There is however, a stabbing dissension amidst the structural economist regarding the amplitude influence of structural shocks. It was contended by a faction of the structural school that, the supply shocks are only experienced in the short-run and have only a temporary influence on the macroeconomy (Ball and Mankiw, 1995). Furthermore, they contended that since the onus is on the policy makers to formulate and execute policies that will promote suitable environment for economic activities in the long term, the unfavorable pressures from the prices of oil as well as food that are extremely erratic in the short-run should not be responded to by the policy makers so as to prevent the economy from driving into recession. Instead, they should concentrate on how "the second-round effect" would be prevented which is liable to take a long time and could lead to recession (Armando, 2009). According to Fischer (1985), the supply shock in itself does not need response from the policy makers if the workers do not resist the real wage.

According to this school of thought, the strategies of the resource based growth would only retard the growth of the economy. For a country to achieve sustainable growth and development, it is quite expedient for her to be industrialized and as well diversify its economy into manufacturing sector. They stressed on the significance of achieving sustainable growth and inferred that economic growth can only be attained in the short run via resource dependency. A lot of empirical research had been conducted in order to assess how the oil price uncertainty influences the economic activities of a country. In G7 countries, Abebe et al. (2019) executed a study on the association of oil prices with the uncertainty 
of economic policy employing monthly data that span between 1997-2018 and also adopted the technique of a nonparametric panel data that permits the trend as well as the coefficient functions to transform as unknown timevarying functional dimensions. Based on the analysis, the oil prices' influence on the uncertainty of economic policy was revealed to be time-varying. The outcome of the analysis also indicated that, the negative oil price estimated time-varying coefficient function in the period in which large increase in the global aggregate demand for oil hike the price of oil. In the final analysis, the findings of this study are significant to endogeneity as well as specifications alternative.

In relation to the study of Adeleke et al. (2019), Nigeria is considered as one of the major net oil producers in Africa. The influence of the price shocks of crude oil on the macroeconomic performance was ascertained spanning from 1980-2016. In the course of this study, the oil price in each quarter was compared with the optimum value indicated during the preceding four quarters, which is adopted to obtain the sharp upward and downward movement in the oil price for capturing the fluctuation in the price. The study employed the analysis of a Panel Structural Vector AutoRegression Model. In view of the outcomes of the analysis, it was indicated that the output's reaction to sharp upward and downward movement in the oil price vary and also revealed that sharp downward movement in the price of oil is accompanied by structural inflation to a greater extent than monetary inflation as a result of the significant decrease in both outputs as well as investment.

Similarly, using the EGARCH model to estimate the series of oil price variation in Iraq, Munaf et al. (2018) collected data from OPEC official statistics on oil prices and HDI. They also applied the technique of ARDL bound test for ascertaining the association of HDI with the fluctuating price of oil in the long run. The outcomes of the analysis exposed the existence of a long run association between the observed variables in the study. Furthermore, there is evidence of a significant influence on human development index due to the instability in the price of oil.

However, Junior and Goodness (2018) ascertained the association of the shocks in oil price uncertainty with key indicators of macroeconomics of a net oil importing nation (South Africa) by adopting the monthly data spanning between 1990-2015. The study engaged the technique of Structural Vector Autoregressive by integrating the realized fluctuation as the oil price uncertainty's indicator in determining influence of oil price uncertainty in the short run. In response to the analysis of the Generalized Impulse Response Functions, the shock of oil price uncertainty was revealed to influence negatively and persistently over time. Hence, the analysis of SVAR shows the significant impact of oil prices exogenetic on the South Africa economy when there is existence of heavy impact in oil price uncertainty.

In the context of disaggregated measures of industrial manufacturing which include indexes for industrial manufacturing, energy and non-energyassociated special aggregates, Elder (2018) revealed that, the influences of the fluctuation in the price of oil are majorly centred on the activities associated with the primary energy generation as well as the oil and gas drilling in relation to other energy-associated market groups. Additionally, the fluctuation in the oil price impacts a wide range of special aggregates amidst the non-energy associated market groups that also include the aggregates sorted by consumer goods as well as business equipment.

Ishmael et al. (2017) appraised the influence of variations in the prices of crude oil on economic development between 1986 and 2015. The study employed the time series data collected from the Statistical Bulletin of Central Bank of Nigeria and were analyzed using the techniques of Johansen's cointegration test as well as the Vector Error Correction Model. In view of the analysis of the data, there exist a co-integration amidst the observed variables while the outcomes of the empirical analysis indicates that the coefficients of ECT possesses negative signs and are significant in all VECMs. Based on the outcomes of the analysis, it was inferred that the country should adopt the policy of floating exchange rate, diversify her economy, build more refineries as well as overhaul the existing ones.

Similarly, Umar et al. (2017) carried out a study in Nigeria investigating the association of oil price with economic development using the annual time series data spanning between 1974-2014. The study adopted the Dickey-fuller generalized least squares unit roots test to examine the stationarity of the observed variables and the Granger Causality Test was conducted to determine the direction of causality. Results revealed the nonexistence of a long-run association amidst the observed variables. Notwithstanding, the granger causality test shows a significant causation of unidirectional that runs from the price of oil to economic development in the short run. In a similar vein, the existence of a significant positive unidirectional causation that flows from human capital to economic development was revealed. Inclusively, a significant positive unidirectional causation that runs from the price of oil to total exports was indicated by the findings. Hence, it is recommended that the price of oil should be stabilized so as to attain high rate of economy growth in the short run.

Mhamad and Saeed (2016) appraised the influence of oil price on economic development in Iraq employing the secondary data spanning between 20002015. The multiple regression model and OLS technique was engaged to accomplish the purpose of the study. It was revealed based on the analysis that, oil price as well as oil export are key determinants of economy development due to the significant and positive influence of oil price on economic development of Iraq.

\section{Methodology}

This study employed the time series data obtained from the Central Bank of Nigeria, publications and the World Bank. This research utilized the Augmented Dickey-Fuller (ADF) unit root test to examine the stationarity among the observed variables. In addition, Least Square method of analysis was engaged to assess the association between the observed variables. The econometric model adopted in this paper takes inflation, gross national income, life expectancy at birth, crude oil prices, government expenditure on secondary school education and unemployment rate as explanatory variable and the elements of human development index 
as dependent variable respectively. The model to ascertain the influence of the price of crude oil on human development is clearly specified as follows:

$G N I=f(C, I, U)$

$S S E=f(C, I, U)$

$L I E=f(C, I, U)$

Where;

GNI - Gross National Income

SSE - Expenditure on Secondary School Enrollment

LIE - Life Expectancy at Birth

C - Crude Oil Price

I - Inflation

$\mathrm{U}$ - Unemployment

Apart from the crude oil price, other variables are treated as control variables to restrain the likelihood of obtaining false outcomes. These variables greatly ascertain the price of crude oil and its influence on human development. Therefore, they are adopted in the course of this study. This can be specified in explicit econometric form as follows:

$G N I=\mathrm{b} O+\mathrm{b} 1 C+\mathrm{b} 2 I+U$

$S S E=\mathrm{b} O+\mathrm{b} 1 C+\mathrm{b} 2 I+U$

$L I E=\mathrm{b} O+\mathrm{b} 1 C+\mathrm{b} 2 I+U$

Where $U$ denotes stochastic error term (with usual properties of zero mean and non-serial correlation) and the expected signs of the coefficients of the explanatory variables are: $\mathrm{b} 1>0, \mathrm{~b} 2>0$.

\section{Data Analysis}

\section{Unit Root Test}

The ADF unit root test was applied so as to examine the stationarity of the data series utilized by the study. The estimation of the unit root test has shown that by employing the techniques of classical estimation, such as the least square to assess the associations with the variables of the unit root presents deceptive conclusions. When there is non-stationarity of variables, a false regression might occur. A false regression essentially reveals a high $\mathrm{R}^{2}$ as well as t-statistics that are considered as significant results, but are with no economic value. Hence, the decision rule of the ADF adopted is by comparing the test statistic of the ADF for individual variable in absolute terms with their corresponding critical value $(\mathrm{CV})$. When the value of the test statistic is more than the $\mathrm{CV}$, it implies the nonexistent of unit root problem but on the contrary, there is existence of unit root problem and if the p-value of ADF is less than the significance value of $5 \%$, it implies that the null hypothesis will be nullified and the alternative hypothesis will be accepted by stating the stationarity of the time series data.
Table 1: Unit Root Test at Level (Augmented DickeyFuller)

\begin{tabular}{|l|r|r|r|}
\hline Variables & $\begin{array}{r}\text { ADF test } \\
\text { statistics }\end{array}$ & $\begin{array}{r}\text { Critical } \\
\text { value }\end{array}$ & S/NS \\
\hline HDI & $/ 0.631796 /$ & $/-1.951332 /$ & $\mathrm{NS}$ \\
\hline LIF & $/ 2.211590 /$ & $/-1.951000 /$ & $\mathrm{S}$ \\
\hline EDI & $/ 0.126815 /$ & $/-1.950117 /$ & $\mathrm{NS}$ \\
\hline INFL & $/-1.897252 /$ & $/-1.950117 /$ & $\mathrm{NS}$ \\
\hline PQLI & $/-3.357042 /$ & $/-1.951332 /$ & $\mathrm{S}$ \\
\hline EXCH & $/-2.816112 /$ & $/-2.971853 /$ & $\mathrm{NS}$ \\
\hline CPC & $/ 0.129849 /$ & $/-1.950117 /$ & $\mathrm{NS}$ \\
\hline COP & $/-0.356703 /$ & $/-1.950117 /$ & $\mathrm{NS}$ \\
\hline SCS & $/ 0.412232 /$ & $/-1.950117 /$ & $\mathrm{NS}$ \\
\hline Sourc: & & & \\
\hline
\end{tabular}

Source: Researcher's computation, 2019

Where;

S - Significant

NS - Not Significant

Table 2: Unit Root Test at First Difference

\begin{tabular}{|l|r|r|r|}
\hline Variables & $\begin{array}{r}\text { ADF test } \\
\text { statistics }\end{array}$ & $\begin{array}{r}\text { Critical } \\
\text { value }\end{array}$ & S/NS \\
\hline HDI & $/-5.558473 /$ & $/-1.951000 /$ & $\mathrm{S}$ \\
\hline EDI & $/-6.324449 /$ & $/-1.950394 /$ & $\mathrm{S}$ \\
\hline INFL & $/-5.676778 /$ & $/-1.950394 /$ & $\mathrm{S}$ \\
\hline EXCH & $/-2.816112 /$ & $/-1.950394 /$ & $\mathrm{S}$ \\
\hline CPC & $/-2.129849 /$ & $/-1.950394 /$ & $\mathrm{S}$ \\
\hline COP & $/-5.208080 /$ & $/-1.950394 /$ & $\mathrm{S}$ \\
\hline SCS & $/-5.964078 /$ & $/-1.950394 /$ & $\mathrm{S}$ \\
\hline
\end{tabular}

Source: Researcher's computation, 2019

Where;

$\mathrm{S}$ - Significant

NS - Not Significant

In responses to Table 2, all the observed variables are stationary at first difference i.e. 1(1), will become the order of integration of the variables, since the $\mathrm{t}$-statistics is greater than their respective $\mathrm{C} \mathrm{V}$ at 0.05 level of significance in absolute term. The outcomes of the ADF reveals significance of carrying out a cointegration test in order to set up a long run equilibrium, since the study variables are not of the same order in relation to their stationarity. 
Table 3: Model 1 (Least Square Method of Analysis)

\begin{tabular}{|c|c|c|c|c|}
\hline \multicolumn{4}{|l|}{ Dereodint Vriabir LIF AT BIRT } & \\
\hline \multicolumn{5}{|l|}{ Lear Squans Merhod } \\
\hline \multicolumn{5}{|l|}{ Dexe 0927199 Tims 1656} \\
\hline \multicolumn{5}{|l|}{ Sample: 19812018} \\
\hline \multicolumn{5}{|l|}{ Aclused 38 observaleni } \\
\hline Vyriable & Coefficient & Std. Exar & t:5tatistic & Prish \\
\hline c & 4533330 & 056965 & ¿ूल65 & 00000 \\
\hline COP & 0001986 & $0.0132 \mathrm{~L}$ & 1503712 & 01419 \\
\hline INFL & $0001+00$ & 0.014419 & 0007009 & 0.9232 \\
\hline $\begin{array}{l}\text { SOCIAI_CONDNUNITY, } \\
\text { SERVICE }\end{array}$ & 0.033272 & 0.006341 & 5246693 & 00000 \\
\hline 3-syuned & 0.786493 & \multicolumn{2}{|c|}{ Men depeddent if } & 4800579 \\
\hline Adjutad R squesed & 6.767654 & \multicolumn{2}{|c|}{ SD depeadear var } & 250622 \\
\hline $5 . E$ efregration & 1338524 & \multirow{2}{*}{\multicolumn{2}{|c|}{$\begin{array}{l}\text { Aktike info criterica } \\
\text { Schwar criterion }\end{array}$}} & 3593651 \\
\hline sum equed resid & 6555200 & & & 3.766038 \\
\hline ag liketitood & -64.27936 & \multicolumn{2}{|c|}{ Batan-Quins cilet } & 3.64992 \\
\hline Fitutistic & 41.74850 & \multicolumn{2}{|c|}{ Dutin. Werson stat } & 1,574307 \\
\hline Trobut-staintic) & 0.00000 & & & \\
\hline
\end{tabular}

Source: Researcher's computation, 2019

From Table 3, the findings reveal the p-value to be $<5 \%$, indicating that the estimated model attained a strong goodness of fit. Furthermore, the analysis shows that, about $76.6 \%$ of the influence of the prices of crude oil on the growth of Nigerian economy is accounted for by the mix of input variables used in this model, while the variation of $23.4 \%$ is caused by the variables not considered in the model. By "rule of thumb", the Durbin Watson statistic has a value between 1.5 and 2.5. Thus, it reveals no suspicion of auto relationship.

Table 4: Model 2 (Least Square Method of Analysis) (1)

\begin{tabular}{|c|c|c|c|c|}
\hline \multicolumn{5}{|l|}{ Deqebdent Veishle EDI } \\
\hline \multicolumn{5}{|l|}{ Lemat Spuare Methed } \\
\hline \multicolumn{5}{|l|}{ Deser 0927 10 Time 1655} \\
\hline \multicolumn{5}{|l|}{ Sarrole 19812015} \\
\hline \multicolumn{5}{|l|}{ Indoded 18 observetions } \\
\hline Vemast: & Coefficieat & Sid. Enoté & IStadiniq & Bnd \\
\hline c & 0255324 & 0009585 & 4633612 & 00000 \\
\hline $\operatorname{cop}$ & -0000731 & 0000239 & 18499 & 02180 \\
\hline INFL & 0.000141 & 0000250 & 0865135 & $05 \pi 0$ \\
\hline $\begin{array}{l}\text { SOCIAL_COMOUUNITY } \\
\text { SESVICE }\end{array}$ & 500003 & 0.000110 & 0.599710 & 05527 \\
\hline Rispured & 0.083507 & \multicolumn{2}{|c|}{ Meses dependent var } & Q.457632 \\
\hline Adjosted R-squared & $0072 \times 6$ & \multicolumn{2}{|c|}{ S.D. drendent vy } & 0.024125 \\
\hline SE of repuestica & $0.02+509$ & \multirow{2}{*}{\multicolumn{2}{|c|}{ Ahaibs info citenon }} & 4514794 \\
\hline Sum maated rstid & 0.029730 & & & -1342497 \\
\hline Log likentizand & 89.8199 & \multirow{2}{*}{\multicolumn{2}{|c|}{ 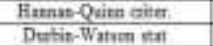 }} & -1453263 \\
\hline f-tatistic & 1036594 & & & $16 \times 9140$ \\
\hline Probat-strintitic) & 0368724 & & & \\
\hline
\end{tabular}

Source: Researcher's computation, 2019

From Table 4, the analysis shows that about $7.2 \%$ of the influence of the prices of crude oil on the growth of Nigerian economy is accounted for by the mix of input variables used in this model, while the variation of $92.8 \%$ is caused by the variables not considered in the model. By "rule of thumb", the Durbin Watson statistic has a value between 1.5 and 2.5. Thus, it reveals no suspicion of auto relationship.
(2)

\begin{tabular}{|c|c|c|c|c|}
\hline \multicolumn{3}{|l|}{ Dependear vantie CPC } & & \\
\hline \multicolumn{5}{|l|}{ Leas Squares Metbod } \\
\hline \multicolumn{5}{|l|}{ Dre 092719 Tine 1550} \\
\hline \multicolumn{5}{|l|}{ 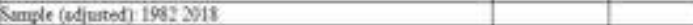 } \\
\hline \multicolumn{5}{|c|}{ induded 37 otserwarion afte squarmeats } \\
\hline Vulatie & Coeffidinat & Sra Enow & Westiatis & Pact \\
\hline c & $-2 / 61061$ & 821965 & -0.393545 & 0.469 \\
\hline COP & 10740.8 & $60+2128$ & 178507 & 0.0843 \\
\hline INFL & 1266557 & 6676190 & 0196000 & 03138 \\
\hline $\begin{array}{l}\text { SOCtAL_ COSGUTUNITY } \\
\text { SERYICE. }\end{array}$ & 9319965 & 313228 & 2.975506 & 00055 \\
\hline HDI & 5651540 & $2002+90$ & 0.23572 & 0.7785 \\
\hline$R \rightarrow$ igared & 0.252309 & \multicolumn{2}{|c|}{ Shen doperdent var } & -1100638 \\
\hline Adfuted R-grared & 8156345 & \multicolumn{2}{|c|}{ 5D dopenderi $\mathrm{xw}$} & 6780494 \\
\hline SE. of veguesion & 821.8695 & \multicolumn{2}{|c|}{ Akafke iafo caiteice } & 1582349 \\
\hline Sule gquiced revid & 12175090 & \multicolumn{2}{|c|}{ Struarz atemion } & $160+612$ \\
\hline Log likelibood & 337829 & \multicolumn{2}{|c|}{ IInny-Quin qiter } & 1590517 \\
\hline F-statintic & 2.699579 & \multicolumn{2}{|c|}{ Duthin Wonven sest } & 1525243 \\
\hline Preb/F-tstivtic) & 0.040055 & & & \\
\hline & & & & \\
\hline
\end{tabular}

Source: Researcher's computation, 2019

Table 5 exposed that, the price of crude oil and HDI significantly and positively influences consumption per capita while inflation rate and social community service, significantly and negatively influence consumption per capita in Nigeria within the study period. Notwithstanding, the p-value of oil price is $>0.05$ significance level signifying the acceptance of the null hypotheses that oil price does not influence significantly the education index.

Table 6: Model 2 (Least Square Method of Analysis) (3)

\begin{tabular}{|c|c|c|c|c|}
\hline \multicolumn{5}{|l|}{ Dependent Yariable PQU } \\
\hline \multicolumn{5}{|l|}{ Las Squares Method } \\
\hline \multicolumn{5}{|l|}{ Dre 092719 True 1656} \\
\hline \multicolumn{5}{|l|}{ Sampie: 19812018} \\
\hline \multicolumn{5}{|l|}{ Dofuded 35 ghuavidisht } \\
\hline Yariable & Coefficient & 5td Error & t-5tatiatic & Prob \\
\hline $\bar{C}$ & 123.0335 & 1910281 & 31.66416 & 00000 \\
\hline COP & -0.161367 & 0.090645 & -1780215 & 0.0840 \\
\hline NAI & 0.086423 & 0098926 & 0873610 & 03885 \\
\hline $\begin{array}{l}\text { SOCIAL CONAMUNITY } \\
\text { SERVICE }\end{array}$ & .0 .251436 & 0.043506 & 5.779362 & 00000 \\
\hline R-ygumed & 0.529601 & \multicolumn{2}{|c|}{ Mesa dependent vut } & 104.6684 \\
\hline Adpasied R-syumed & 0.514566 & \multicolumn{2}{|c|}{ S. depedient var } & 2212160 \\
\hline SE of roperaion & 9.526002 & \multicolumn{2}{|c|}{ Akaike info citerive } & $7+45238$ \\
\hline Sum scuared resid & 3085353 & \multicolumn{2}{|c|}{ Schwarz aiterica } & 7617616 \\
\hline Leg Brelitood & -137.4595 & \multicolumn{2}{|c|}{ Ëannm-Quinn criter. } & 7506569 \\
\hline 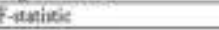 & 5517333 & \multirow{2}{*}{\multicolumn{2}{|c|}{ Datio-kyation its }} & 173490 \\
\hline Prob(F-staciutic) & 0,000000 & & & \\
\hline
\end{tabular}

Source: Researcher's computation, 2019

From Table 6, it is revealed that crude oil price as well as social community service influence adversely but significantly the physical quality of life index and it also shows a favorable and significant influence of inflation rate on physical quality of life index. In view of these outcomes, the null hypotheses should be accepted that, oil price does not influence significantly the physical quality of life.

\section{Discussion of Findings}

This study investigates the uncertainty of oil price influence on the activities of Nigerian economy with regard to human development and results of the 
analysis reveals positive and significant influence of the volatility in the price of crude oil on consumption per capital in Nigeria. This implies that, as the crude oil continues to increase, there will also be a correspondent increase in consumption per capita and this will influence the life style of Nigerians positively. During the study period, consumption per capita was greatly influenced by the price of oil. When there is an upsurge in the price of oil, it provides avenue for Nigeria to raise her budget and embark on huge projects without the intention of increasing development. This makes more money to be in circulation in the economy. This result attests to the outcome of the study by Munaf et al. (2018), which shows a significant influence of oil prices volatility on consumption per capital. This is however contrary to the outcomes of the study carried out by Offiong et al (2016), revealing that the shocks of oil price adversely affected the economy of the state.

Inclusively, the outcomes of the analysis reveal that, physical quality of life is adversely influenced by the crude oil price. The coefficient of 0.16 indicates that an upward movement in the price of crude oil will result in a reduction in the physical quality of life by $16 \%$, implying that the increase in the oil price does not improve the quality of life in Nigeria. Therefore, it can be inferred that the price of crude oil has little significance on the economy of Nigeria. This outcome is supported by the study of Charles et al. (2019), indicating that oil price uncertainty does not impact significantly on the wellbeing of the society.

\section{Conclusion and Recommendations}

This study appraised the influence of oil price fluctuations on the economic development of Nigeria. One of the basic goals of macroeconomic variables is to measure the sustainability of a country's economy in aggregate term in relation to how a particular variable impacts on the general performance of such economy. Based on this, the study deemed it to be of great benefit by disaggregating the variables with the main purpose of investigating how the price of oil has impacted the consumption per capita, physical quality of life, human development, education and life expectancy. In view of the analysis, it was concluded that crude oil price has a positive and insignificant influence on life expectancy, negative and insignificant influence on education development index, a positive and significant impact on consumption per capita, and negative as well as significant influence on physical quality of life index in Nigeria.

\section{References}

Abebe, H., Russell, S. and Xibin, Z. (2019). Oil prices and economic policy uncertainty: Evidence from a nonparametric panel data model. Energy Economics, Vol. 83, 40-51.

Adeleke, O., Harol, N. and Adebayo, K. (2019). Crude oil price shocks and macroeconomic performance in Africa's oil-producing countries. Journal of Corgent Economics and Finance, Vol. 3, Issue: 1.
Alley, I., Asekomeh, A., Mobolaji, H., and Adeniran, Y. (2014). Oil price shocks and Nigerian economic growth. European Scientific Journal, 10(19), 375-391.

Armando, F.D. (2009), Latin American Structuralism and Economic Theory, CEPAL Review No. 98, 175-195.

Baumeister, C. and L. Kilian (2015). Understanding the decline in the price of oil since June 2014. Journal of the Association of Environmental and Resource Economists, Vol. 3, No:1, 131-158.

Charles, Felicia, Jonathan, Okoro, Aja and Kenneth (2019). Oil Price Fluctuation, Oil Revenue and Well-Being an Nigeria. International Journal of Energy Economics and Policy, 9(1), 346-355.

Demirbas, A., Al-Sasi, B. O., Nizami, A.S. (2017). Recent volatility in the price of crude oil. Energy Sources, Part B: Economics, Planning and Policy, 12(5), 408-414.

Elder, J. and Serletis, A. (2010). Oil price uncertainty. Journal of Money Credit and Banking, 42(6), 1137-1159.

Fischer, S. (1985), Supply Shock, Wage Stickiness and Accommodation, Journal of Money, Credit, and Banking, 17: 1-15.

Ishmael, O., Matthew, T. R. and Park, I. (2017). The Impact of Changes in Crude Oil Prices on Economic Growth in Nigeria. Journal of Economics and Sustainable Development, Vol.8, No:12.

Junior, T. C. and Goodness, C. A. (2018). The effects of oil price uncertainty on economic activities in South Africa. Journal of Cogent Economics \& Finance, Vol. 6, Issue: 1.

Mankiw, N. G. (1995). The growth of nations", Brookings Paper on Economic Activity, pp. 275-326.

Mhamad, S.H. and Saeed, S.T. (2016). Impact of Oil Price on Economic Growth: Empirical Evidence from Iraq. Journal of Economics and Sustainable Development. Vol.7, No.14, 2016.

Munaf, M., Sundus, J. S. and Shatha, S. D. (2018). Impact of Oil Price Fluctuations on Human Development: A Standard Study of Iraq.

Offiong, A.I., Atsu, I.A., Ajaude, E. \&Ibor, B.I. (2016). The Impact of Oil Price Shocks on the Economic Growth and Development of Cross River State, Nigeria. International Journal of Financial Research, Vol. 7, No. 4. 
Ogwumike, F. O and Ogunleye, E. K. 2008. Resourceled development: an illustrative example from Nigeria. [Online]. Available at http://onlinelibrary.wiley.com/doi/10.1111/j.14 67-8268.2008.00182.x/full

Sommer, M. (2002), Supply Shocks and Persistence of Inflation, retrieved on March 31, 2014, http://econ.jhu.edu/wpcontent/uploads/pdf/papers/WP485SommerInfl ation_12-02.pdf

Umar, M. G., Aliyu, I. B. and Ahmad, M. (2017). Oil Price Fluctuations and Economic Growth in Nigeria. Australian Journal of Social Science, Vol. 3, pp. 1-16. 